\title{
Historians, superhistory, and climate change
}

\author{
J.R. McNeill
}

That we are now in an age of rapid climate change is disputed in only in a few places, and there mainly for political purposes. Concern over what changing climate might mean has motivated a surge of research into climate history, using all manner of proxy evidence to inquire into temperature conditions, droughts and floods, the frequency of hurricanes and other major storms, El Niño events, and much else besides.

Only a small proportion of this new evidence on climate history comes from textual sources, the familiar terrain of the historian. Instead it comes from tree rings, ice cores, speleothems (mineral deposits in caves), fossil pollen, marine corals, varves (layers of silt or clay on the seafloor) among other places. Climate history is undergoing a renaissance thanks to all these new data. At the same time, as I will explain below, new evidence of other sorts, pertaining to other sorts of history, is also cascading forth.

Fifty or sixty years ago, under the influence of Fernand Braudel and his friends, professional history took a turn toward the social sciences. Thirty years ago, under the influence of other French scholars, no friends of Braudel, professional history took a "linguistic turn". Now it looks to be taking a "natural science turn". Historians seem to be rather like windmills, turning this way and that in response to the prevailing winds of other intellectual disciplines. There is nothing wrong with that. Surely it is often preferable to adjust one's research methods in response to innovations, whether they come from physics or from literary studies, rather than to remain resolutely unaffected by changes in intellectual life. 
In this chapter, I will try to explain some of the opportunities and challenges presented by the volcano-like eruption of new historical data from the natural sciences, with special attention to climate data and what some prominent historians have thought about climate. I will also raise the question of how the new data might affect the choices historians make about the scales on which they pursue their research, in particular the logic of selecting a global scale.

\section{Superhistory and why historians need to overcome the text fetish}

The past, always a foreign country, is growing more foreign to textbased historians.

If historians wish to improve their - our - ability to address puzzles from the past (and for that matter to remain central in the study of history), they - we - need to embrace what is fast becoming superhistory. Superhistory amounts to a methodological revolution by which textual evidence jostles together with that of ice cores, marine sediments, peat bogs, stable isotopic ratios, and the human genome - and a few other genomes as well. The revolution takes historians to new terrain, to geo-archives and bio-archives, as well as to the more familiar archives containing old documents. Climate history is part of this revolution, so far perhaps the biggest part.

While careful analysis of documentary texts is the bread and butter of the historical method, historians for at least a century have found ways to use other sources such as art, literature, and the findings of archeologists. For those times and places at which abundant texts, art, and archeology overlap, such as the Roman Mediterranean of the first and second centuries CE, the interplay among specialists using different sorts of sources is a long tradition and a fruitful one. Such melding of sources has yielded information and insights rarely matched for times and places with fewer texts, less surviving art, or low appeal to archeologists. So superhistory has its precedents, and perhaps should be regarded as an expansion upon a methodological tradition (Myrdal 2012).

Superhistory nudges us, and perhaps drives us, in the direction of global history. Texts come in languages, and those languages some- 
times correspond to political structures such as states and nations. Japanese is spoken in Japan and almost nowhere else; similarly with Danish and Denmark. Thus text-based historians who know these languages are tempted to write their histories on the national scale or smaller. Moreover, much textual documentation has been produced by bureaucrats employed by states and concerns the business of states. Thus textual history - what we still call history - exhibits a strong bias toward the affairs of nations and states. It encourages historians to accept nations and states as appropriate units of analysis, which for some questions they are and for others they are not. This tendency towards national-scale history has probably weakened in recent decades; the advent of superhistory will weaken it further.

The evidence of superhistory bears much thinner relationships to nations and states, and encourages historians to play around with other units of analysis, both larger and smaller. Of course, textual historians for centuries have worked on a variety of scales. Some attempted global history or thematically defined subsets of global history, such as warfare, marriage, or agriculture. The new torrents of climate evidence and the genomic data easily lend themselves to global-scale analyses. Thus the evidence from the natural sciences that is now spewing forth invites a new generation of historians to adopt world-historical perspectives. And those scholars already employing world history perspectives probably find the new evidence of superhistory more interesting, exciting, and compatible with their ambitions than do other historians. ${ }^{1}$

Superhistory bears a cousinly resemblance to Big History. Scholars such as David Christian (in Australia) and Fred Spier (in the Netherlands) have spearheaded a very long-term perspective on human affairs, which they call Big History. It involves situating the human story inside the story of life on Earth, inside the story of Earth, inside the story of the solar system, our galaxy, our Universe. At this scale, mind-boggling for most historians, Christian and Spier find patterns that are not readily visible on the brief time scales familiar to historians and archeologists. They see, for example, recurrent stories of energy capture and advancing complexity, in celestial bodies and civilizations alike, over time (Christian 2005; Spier 20 I0).

Big History, moreover, necessarily requires a plurality of sources, 
disciplines, and perspectives. Big historians such as Christian (a historian of imperial Russia by background) and Spier (an anthropologist with an undergraduate degree in biochemistry), must wrestle with cosmology, astronomy, earth science, evolutionary biology, paleoanthropology, archeology, as well as history as conventionally understood. Big History is stunning in its ambition, and requires an Aristotelian reach on the part of its practitioners. No wonder there are comparatively few who practice the art.

Superhistory calls for something less. First of all, it is not concerned with the origins of the Universe, stars, planets, galaxies, solar systems, or life. Nor is it concerned with much of the first four billion years of life on Earth. Rather, it is concerned with the human experience and only the human experience. It is a few notches less ambitious, and less demanding, than Big History. But it shares with Big History a recognition of the value of approaches to the human past through multiple disciplines and multiple types of sources. In this chapter I maintain that historians, like it or not, would be well advised to accept the implications of superhistory and acquaint themselves, where appropriate to their subjects, with the evidence from the natural sciences. But I do not claim that they need to become practitioners, or devotees, of Big History. While I have the greatest respect for the achievement of Christian (2005) and Spier (20 IO), and am among those fascinated by the larger patterns they identify, I do not yet see that their elegant nesting of human history inside so many other histories necessarily changes the way historians should see their subjects. In a sense, Big History changes everything and changes nothing. It tells us that our species' story conforms to a larger pattern. But it does not change our species story. In a nutshell, superhistory represents a revolution in historical methods but no change in subject; Big History is a revolution in subject, perspective, and method.

Before going any further, let me turn to some of the dark sides of superhistory. Among the risks one runs in globalizing history is the temptation to seek simple explanations for things outside one's area of expertise. This temptation operates within history itself, and a fortiori with respect to scholars venturing beyond its traditional confines and dabbling in superhistory. So, historians of modern or late imperial 
China for example, who would never accept a simple explanation of the fall of the Qing dynasty, are tempted to accept one for the fall of the Maya city-states or for the empire of Mali. This is only human: it would take time and effort to educate oneself in the complexities of Yucatan and Guatemala in the eighth to the tenth century, or West Africa in the fourteenth and fifteenth. Who can justify the time?

Historians who forage in other disciplines to enrich their sense of the past run a still greater risk. Climatology, genetics, historical linguistics, isotopic analysis, and other specialist realms, of course have their complexities and controversies, and informed assessment of them requires some considerable education in fields most historians have steadfastly avoided since secondary school. Hence the powerful temptation to accept simplistic explanations - or, what is probably worse, to ignore novel sorts of evidence and pretend that texts are all that matters.

That last position, while comforting to those of us trained to examine texts, is increasingly naïve and intellectually unsustainable. By fetishizing documents, professional historians for nearly 200 years have presented caricatures of the past based on what were often accidents: what happened to get written down, and, of that, what happened to be kept, and, of that, what happened to survive rot, fires, floods, ravenous insects, important people trying to hide a sin or two, or any of the several other hazards to which paper, papyrus, clay tablets, or oracle bones might be subject. As a result, a great deal remained hidden to historians, many of whom found it congenial and comforting to pretend it therefore did not happen. ${ }^{2}$

Confining oneself to data present in texts is now a worse method than ever before. Nowadays the chemically-inclined physical anthropologists can tell us, by examining strontium-calcium ratios in bone and teeth, where the food was grown that nourished any particular body. They can tell which alpine valleys Ötzi the Iceman frequented during his childhood, and, if given a tooth, could tell us whether or not President Obama was raised in Hawaii and Java as opposed to Kenya, as a remarkable proportion of Americans believe (not that strontium-calcium ratios would likely change their opinions in the matter!). They can tell us, from chemical analysis of human remains, that Italians in $900 \mathrm{CE}$ ate almost 
no seafood unless they lived on the coast, but that by $\mathrm{z} 300$ even inland Italians ate it routinely.

The microbiologists can tell us which antibodies prevailed in which populations, providing indications of past experience of bubonic plague or malaria. From teeth, they can tell us which skeletons in London cemeteries from 1348 belonged to bubonic plague victims and which did not. They can map the geography of the I 9 I 8 influenza epidemic's intensity at least as well as can historians working with texts. The geneticists can tell us that the founding mothers of the Icelandic population were overwhelmingly from Britain and Ireland, presumably abducted or purchased by Norsemen en route to settlement in Iceland in the decades after $874 \mathrm{CE}$, something on which the Icelandic texts are mute and archeology unhelpful.

Microbiologists and geneticists have also resolved what for Americans was a detail of some importance: that Thomas Jefferson did indeed father children by a slave woman named Sally Hemings. Jefferson's paternity of Hemings' children, once widely doubted, is now denied only by his fiercest apologists. It is not merely the distant past that new methods illuminate, although their value is indeed greater in that very foreign country because of the paucity of texts.

It may be disconcerting for most of us, but history is in the throes of a methodological revolution or two, one for which none of us are trained and few of us prepared. To the extent that we shy away from it, we will be shunted further to the margins in some of the important debates of our time, such as that over the significance of climate change, and - incredible as it may seem to historians perhaps also in some discussions of the past. To the extent that we embrace it, we will have a voice in all these conversations.

I will finish this discussion with a cheerful example of the promise of superhistory drawn from my own experience. While a doctoral student in the early I980s, I grew interested in the history of yellow fever in the Caribbean. At that time, no one knew if yellow fever was originally an American or an African disease, no one knew whether its vector, a particular species of warmth-loving mosquito, was American or African, and no one knew why the texts seemed to show a stronger prevalence of the disease in the eitghteenth and nineteenth centuries than before. (I should also say that as far as I 
could tell no one other than myself seemed to care about that last point.) I wrote an amateurish paper on yellow fever in the Caribbean, thinking I would follow up with more research soon.

Fortunately for me, I let life intervene for a quarter century before I returned to the subject. In the interim, geneticists had shown that the yellow fever virus circulating in the Americas is of African origin; and that the vector mosquito is also a migrant from Africa. These new data help explain the immunological basis for a racist discourse of difference between Africans and others in the Caribbean, one that claimed Africans were more fit than others for labor in the torrid zone. (Being African or black was widely thought to be important but in fact was irrelevant; disease resistance to yellow fever was based on whether or not one spent one's childhood in an endemic yellow fever zone such as most of West Africa - and perhaps whether one's ancestors over hundreds of generations had done so. Many Africans and many blacks had neither acquired nor heritable resistance to yellow fever.) But many did carry immunity to yellow fever, and resistance to malaria as well. And so once these diseases became established and endemic in the West Indies (by about I 650), it seemed to most observers (or, more precisely, to those whose opinions happened to get written down and preserved) that African bodies were by nature suited for labor in the Caribbean.

Meanwhile, historical climatologists studying the chemistry of the shells of sea creatures had shown that the warming at the end of the Little Ice Age (already known as a European phenomenon in my student days) extended to the Caribbean. As the Caribbean got warmer, conditions improved for the yellow fever mosquito. "Vector abundance", as specialists put it, is crucial to the prevalence of mosquito-borne diseases, so climate's suitability from the mosquito point of view was an important factor affecting the risk presented by yellow fever. Climate scientists, in the interim, also had constructed a database of El Niño events over the centuries, allowing respectable hypotheses about drought frequency and varying conditions for mosquito breeding.

So, by 2005 , without having done any of the research myself - which indeed I was not competent to do, having sidestepped microbiology and climate science in my education - I was in a 
much stronger position to make sense of the fragmentary textual record concerning yellow fever outbreaks available in a handful of archives. All I had to do was read the recent work of a handful of scientists. And the book I wrote on these subjects was more convincing than it could have been in 1985 , thanks to the emergence of new data from the natural sciences - convenient bits of superhistory (McNeill 2010).

Natural scientists provided these convenient bits of superhistory not because I wanted them, but because such research suited their own agendas. Had it been up to me, I would have asked for research on some other issues pertaining to yellow fever as well (particularly the unresolved issue of whether or not there is any heritable resistance or even immunity to the disease). Unfortunately for me, I was not in a position to direct the efforts of microbiologists and geneticists. Few historians, if any, will ever be in that position. This, then, is a limitation of superhistory: the findings pouring forth result from research agendas that historians do not shape, and generally do not even influence in the slightest. But this is only a limitation. And if historians join interdisciplinary research teams before those teams fully set their research agendas, the odds of affecting those agendas improve dramatically. This limitation is not reason enough to scorn the data of superhistory.

\section{Why historians need to elbow their way into the climate change debates}

A big part of the new superhistory, and the only part I will deal with henceforth, concerns the history of climate. So far the archeologists and paleo-anthropologists have gone further than historians in taking historical climate change seriously. There are several possible reasons for their eagerness to embrace climate change in their work. One is that they live off research grants to a larger extent than do historians, and to elbow their way to that feed trough amidst the legions of cancer researchers and hunters of the Higgs boson, they need to make plausible claims to be doing relevant and useful science. And among the few routes open to them is to offer results that speak to societies' experience with climate change. A second 
possible reason is that because they typically deal with sparse evidence $-\mathrm{a}$ few bones and potsherds - any new evidence looms large for their interpretations.

Historians, at least most of us, do not compete at the same trough as natural scientists. Our survival is not so directly tied to providing useful science, so our quests for funding do not propel us toward the issue of climate change. And most of us, at least, do not thirst for new kinds of information. We have enough of the old sort to keep us occupied. There is no shortage of texts awaiting examination or re-examination in light of new concerns. But all that, like the limitations mentioned above, is not reason enough to shy away from the new data offered by natural scientists, especially on climate.

Scientific American, an excellent popular science magazine, recently printed a fine overview article on current climate change and its implications. The author, a distinguished earth scientist from one of the world's foremost research universities, makes several trenchant arguments for the importance of the ongoing pulse of climate change. Then he writes:

Human civilization is also at risk. Consider the Mayans. Even before Europeans arrived, the Mayan civilization had begun to collapse thanks to relatively minor climate changes. The Mayans had not developed enough resilience to weather small reductions in rainfall. The Mayans are not alone as examples of civilizations that failed to adapt to climate change (Caldeira 20 I2: 83).

This is all he says about the potential significance of climate change for humankind. And, unfortunately, it is probably mostly wrong. According to current expert opinion, the Maya collapse - if that is the right word for it - consisted of a decentralization and de-urbanization that took place over several decades in the ninth and tenth centuries. It was bad for ruler, but ordinary Maya might well have regarded it as a liberation. (They left no texts so we cannot know for sure). Royal demands for tax and conscripts disappeared. With respect to climate, a severe and prolonged drought, one of three Central American "megadroughts" of the past 2,00o years - not "small reductions in rainfall" - deflated the rural economy. Many 
things contributed to the "collapse"; specialists point to soil erosion, increased warfare, and half a dozen other unfavorable trends. And so to say it occurred "thanks to relatively minor climate changes" is doubly wrong - the climate changes were major and they provide only part of any explanation. Lastly, resilience to fluctuations in rainfall was probably among the strengths of the Maya, who had sophisticated water management (Stahle et al. 20 I I; Beach et al. 20 I 5).

The Scientific American article (Caldeira 20 I 2) illustrates some of the hazards of interdisciplinary work mentioned above. The author accepted blithe assertions about the Maya, without probing the specialist literature. Perhaps he felt he was too busy to research an issue tangential to his article; perhaps he trusted a careless research assistant too much.

My point is not to castigate a distinguished earth scientist for writing a few sentences of ill-informed history, or not merely to do so. It is, also, to argue that historians must bring their skills and sensibilities to the issue of climate change. Otherwise oversimplified histories penned by earth scientists, journalists, environmental activists, and climate deniers will prevail unchallenged.

\section{What have historians done with climate so far?}

The great majority of professional historians for the last 200 years have completely ignored any possible significance of climate. In many cases, this neglect is justified: climate had nothing to do with King Henry VIII's unhappy marriages or Marx's debts to Hegel or any of countless other matters important to historians. But on bigger scales, when one considers the trajectories of regions and societies, this persistent neglect is surely unjustified.

When thinking about historians and climate, and about how climate affected human history, it is important to draw a fundamental distinction, one that historians, and others, have from time to time ignored. That distinction is between climate regime and climate change. By and large, until quite recently, among those who attributed any significance in human affairs to climate, it was climate regime, not climate change, they pointed to.

Once upon a time, most thoughtful and educated people believed 
the global climate was fixed. Some thinkers, from the time of Theophrastus - a student of Aristotle's - if not before, thought that local climates might change. Aristotle himself in one passage implied climate had changed over the centuries in the Argive plain around Mycenae, and, further, suggested that pattern might be more general.

In the time of the Trojan wars the Argive land was marshy and could only support a small population, whereas the land of Mycenae was in good condition (and for this reason Mycenae was the superior). But now the opposite is the case, for the reason we have mentioned: the land of Mycenae has become completely dry and barren, while the Argive land that was formerly barren owing to the water has now become fruitful. Now the same process that has taken place in this small district must be supposed to be going on over whole countries and on a large scale.

This passage, so far as I know, is a rarity among ancient thinkers, who preferred to believe that climate was fixed except perhaps locally in response to loss of forest cover. (The indispensable guide to ancient environmental thought is Glacken 1967). And there is some difficulty of interpretation here: Aristotle did not mention climate specifically, even though the passage quoted above appears in Book I of his Meteorologica. Perhaps he had something else in mind, such as drainage. If Aristotle did have climate change in mind, as seems most likely to me, he was out of step with his age. The fact remains that (as far as the textual evidence can tell us) thinkers of the ancient world typically regarded climate as fixed rather than changeable. Modern historians, on the rare occasion when they gave the matter any thought, normally agreed.

Many deep thinkers, however, supposed that climate regimes shaped the essence of societies or the characteristics of peoples. Herodotus, Hippocrates, Aristotle, Ibn Khaldun, Montesquieu and thousands of shallower thinkers shared this view. The various bands of latitude, they maintained, each had their own climates, and each climate had its impact on people's abilities or society's characteristics. The fourteenth-century polymath from today's Tunisia, Ibn Khaldun (1967: 58) for example, following the ancient Greeks, claimed that: 
The human inhabitants [of the $3 \mathrm{rd}$ and 4 th zones, bands of latitude in his scheme] are more temperate in their bodies, colour, character ... such are the inhabitants of the Maghrib, Syria, the two Iraqs, Western India, and China, as well as Spain; also the European Christians who live near by, the Galicians ... Iraq and Syria are the most temperate of all these countries.

Ancient and medieval writers typically thought, in short, that climate regimes were very important in human affairs because climate shaped, or even determined, temperament and intelligence. More recent commentators on these issues, such as the Baron Montesquieu, thought in a similar vein. His influential book, L'Esprit des Lois (I 856 ) is substantially devoted to climate's supposed impact on temperament. Montesquieu, like his predecessors, attributed great importance to climate regime, but did not normally think in terms of climate change. That viewpoint was logical enough: no one lived long enough to see climate change in operation.

In the course of the nineteenth century, the idea that global climate might change acquired currency. Geologists convincingly demonstrated the ebb and flow of glaciers, for example, a phenomenon which seemed to require changes in climate. Some deep thinkers began to modify their views, and admit changing climate, at least on regional scales, as a possible motor in human affairs.

One of the first prominent historians to do so was the Englishman Arnold J. Toynbee. He held a marvelously contradictory set of positions about the role of climate in human history. His significance, perhaps, is that he was a transitional figure, who attributed importance both to climate regime and to climate change.

Toynbee was born in London in I 889, in the same week as Adolf Hitler and Charlie Chaplin. He was a scholarship boy at a famous public school, where he learned Latin, Greek, and German very well. He had a humanistic education with minimal exposure to natural science. After distinguishing himself at Oxford and logging a stint in the Foreign Office during World War I, he settled into his work as a historian - of everything.

Few historians outworked him: by the time he was 28 , he had written 7 books. Then he hit his stride, and from I 92 I to 1974 he 
published, on average, upwards of 200,000 words a year. Between I 947 and his death in 1975 he was the most famous historian alive. Perhaps no other historian has achieved such celebrity - before or since.

His most famous work was his I o-volume Study of History, which he began to write in the mid-I920s. The cartoon version of it is that human history over the past 6,000 years featured 2 I civilizations (he eventually admitted a few more), each of which followed roughly the same trajectory.

He believed that the proper unit of historical analysis was not the state or nation, but the civilization. All civilizations arose, he believed, as creative and original human responses to specific challenges. Their eventual demise he attributed to failure to respond to subsequent challenges, usually political and economic. The whole scheme had a mystical quality to it. Its greatest merit was its scope: true global history.

In the first volume of A Study of History, published in I934, he included a section on the insignificance of environment as a factor in the rise of civilizations. Favorable climates did not necessarily promote achievement, greatness, or anything in particular. Nor did harsher climates necessarily make achievement harder. The opposing view, which he sometimes called "The Hellenic Theory" and attributed to Hippocrates and Herodotus, he disparaged.

However, by the middle of the first volume, Toynbee had modified his position somewhat: changes to climates could be important. In discussing what he called Egyptaic civilization, he found that it arose as a human response to a challenge, specifically the desiccation that he - following the archeologist Gordon Childe - believed affected all of North Africa and southwestern Asia around 5-6,000 years ago. To cope with growing aridity, peoples of the Sahara poured into the Nile valley and built dikes, dams, berms and canals, and more broadly, built a civilization.

Moreover, he decided that Sumeric (to use his preferred term for what others call Sumerian) and Minoan civilizations arose as responses to the same challenge of climatic deterioration. Several other civilizations arose from the challenges of "untamed" environments, whether tropical rainforests (the Maya) or arid plateaux 
(in the Andes). In every case, changing or difficult environments formed part or all of the challenge that provoked the response of creating a civilization. But, as he pointed out frequently, the environmental challenge alone was insufficient explanation: not every case of desiccation gave rise to a civilization. Indeed, most did not.

While Toynbee's giant book is full of contradiction and inconsistency on this point, most of the time, despite his initial protestations against it, he granted environmental factors a significant role in provoking the origins of civilizations. Climate changes fit nicely into his overarching scheme of challenge and response.

He put his faith in climate regimes as well as climate change. He not only adapted desiccation theory to help explain the origins of three Eastern Mediterranean civilisations, but he posited what he sometimes called "the Golden Mean". Some climates were too easy and presented no challenge. Some were too harsh, and presented challenges that could not be overcome. Others offered a challenge that was "just right".

He used this concept to explain, for example, the success of New Englanders in dominating - as he saw it - the history of North America. In a most confusing argument, at least to an American, he finds the New England environment more stimulating than that of French Quebec, Dutch New York, English Virginia, or Spanish Mexico. In an equally confusing passage, he attributes the economic vitality of the North of England to the quality of its environment, and contrasts that to the softer challenges of the Thames valley and the Home Counties. He draws a line between the estuaries of the Severn and the Humber, to the northwest of which the environment provides a bracing challenge, and to the southeast of which it does not (Toynbee I934-6I, 2: 64-73).

Toynbee (I934-6I, 2: 65) concludes his discussion of climate and environment in Britain by claiming that the contrast between the "legendary Scotchman - solemn, parsimonious, precise, persistent, cautious, conscientious and thoroughly well educated - and the legendary Englishman - frivolous, extravagant, vague, spasmodic, careless, free-and-easy, and ill-grounded in book learning - follows the same lines, and corresponds to the same contrast in the local physical environment ...”. 
Since Toynbee wrote these words in the I930s, the economic history of Britain has not been kind to his interpretations. The southeast of England has flourished, and the industrial north declined in relative terms. The contrast between the legendary Scotchman and the legendary Englishman, which must have struck some readers as strange even then, now seems ludicrous.

In these passages he does not specify what he means by "environment". Almost everywhere else he brings it up, he mainly means climate, and here descriptors such as "near-Arctic" for Quebec suggest he had it in mind here too.

When it came to the decline of civilizations, a matter of equal concern to Toynbee as their rise, he left out climatic variables altogether. Declines were a matter of weakening moral fiber among cultural and political elites. On this, at least, he was consistent.

Toynbee's ideas show that it is not only distinguished earth scientists who may entertain simplistic ideas about the relationships between societies and climates. Great historians with Oxford educations can make a hash of it too. Historians of today will have to do better to deserve a voice in today's climate debates and to earn the attention of those seeking wisdom in climate history. Fortunately, we can do better, and some have already done so.

More recent historians, to whom I will now turn, if interested in climate at all, saw matters almost precisely the other way around from Toynbee: climate change mattered more than climate regime, and it mattered in the fall of societies, states, and civilizations more often than in their rise. Where Toynbee sometimes saw climate crisis as the spur to creative moments, more recent historians usually saw only crisis.

Among more recent historians the most prominent to inquire deeply into climate's role in human affairs was Emmanuel Le Roy Ladurie, born in 1929 to a farming family in Normandy. In the I950s Le Roy Ladurie began to research climate change, mainly in Europe, for the period after Iooo $\mathrm{CE}$. He began publishing on climate, harvests, subsistence crises and so forth in I956, and eventually took on board the evidence of glaciers and tree rings - proto-superhistory - in a book (Le Roy Ladurie I 967) called Histoire du climat depuis l'an mil. ${ }^{3}$ While amassing evidence for changing climate, especially 
of the Little Ice Age, Le Roy Ladurie made minimal claims for the significance of climate change outside of areas marginal for human occupation such as Iceland and Greenland. It was an unusual history book, both for its methodological innovations, and for its conclusion which was, in essence: my subject, on which I have labored mightily for ten years, is unimportant for human history.

In 20I0, I had the opportunity to ask Le Roy Ladurie about his climate history work. He told me, and he has told others the same thing, that in the I950s and I960s he was afraid to claim significance for climate variables. He disguised his true views. He was then making his way upward in French academia, and feared (probably correctly) that being labeled a climate determinist or environmental determinist would derail his career. His friends and those whose good opinion he needed in order to flourish, were Marxists or at least marxisant, as he was himself. (He was a member of Parti Communiste Français from 1945 to I963, but inactive after the Soviet suppression of the 1956 Hungarian uprising). The eminences grises of French academia would surely have reacted with scorn if he were to suggest, for example, that the French Revolution happened in part because of adverse climate shifts of the I78os. Such conformism did not hurt Le Roy Ladurie's career: he became a member of the Collège de France in 1973 and was later director of the Bibliothèque Nationale. After reaching the pinnacles of French intellectual life, Le Roy Ladurie in effect recanted, publishing a three-volume work in which he claims a much larger role for climate change in shaping human events (Le Roy Ladurie 2004-2009).

Le Roy Ladurie's prominence - he was for a while among the most famous historians in the world and is still widely, and justly, admired - helped open the subject of climate change for other textbased historians to explore. So too did the example of archeologists who increasingly took climate change seriously - an important story I will not try to sketch.

Toynbee and Le Roy Ladurie stood as giants in the historical profession. Their books reached a wide public. Their specialized work, although not always their broader efforts, enjoyed the admiration of their peers. No one since has achieved such stature, certainly among those taking positions on the significance of climate in 
history. Nonetheless, an adventurous minority of historians, when looking for more than rises and falls, found climate change almost everywhere. In the I980s, Joe Miller (I988) used new information on the history of drought to help explain the waxing and waning of the slave trade in Angola. In drought years, vulnerable people had to sell their children or surrender themselves to the more fortunate, who in turn sold some of them to transatlantic slavers. In the I990s, Wolfgang Behringer (I 999) offered a bold new interpretation of the witch craze in western European history: the bad years of the Little Ice Age, especially i 560-I660, sharpened the persecution of women held to be witches in early modern Europe. They were accused of, among other crimes, arranging bad weather through their pacts with Satan. Climate fluctuations, thus, pertain to social history as well as to harvests and the various collapses of this or that dynasty.

As one might expect, the history of arid and semi-arid regions more often suggests a strong role for climate change. Where rainfall just barely allows agriculture, and people survive with little margin for misfortune as a result, small droughts could have big consequences - rather like modest reductions in average temperatures in Scandinavia. The Middle East offers a fine example. Recently, historians such as Richard Bulliett (2009) and Ronnie Ellenblum (20 I 2) have offered climate-driven analyses of the economic and political history of the region in medieval times. The same centuries that brought warmer and moister weather to Europe, brought cold and drought to the Middle East. From 950-I 200 or so, conditions frequently proved unfavorable for farming. The Nile more frequently carried too little water for Egyptian agriculture. Dry farming in Iran often failed altogether. States that depended on revenues from agriculture collapsed and opportunities for invaders, such as the Seljuk Turks from Central Asia, improved markedly. These historians, both essentially text-based scholars, but influenced by the findings of natural scientists, have opened exciting new vistas on the medieval Middle East.

For a later period of Middle East history, Sam White has done something similar (White 20 I I). Using a large amount of proxy evidence from historical climatology, as well as the familiar texts of historians, White has made a strong case for the relevance of drought 
and cold - the Little Ice Age - to a series of revolts in the seventeenth-century Ottoman Empire. White was not the first to suggest a connection between the Little Ice age and the Celali rebellions, but he argues the case much more carefully and convincingly than his predecessors. None of these authors, Bulliet, Ellenblum, White, may be fairly accused of reducing Middle East history to climate. But all of them make climate changes one of the driving forces behind deep political and cultural changes in the region.

Chinese history has become an especially welcoming environment for arguments based on climate change. A telling indication is the recent work of Timothy Brook. Brook is a text-based historian of imperial China with formidable abilities in East Asian languages, well aware of rival explanations for dynastic cycles. Brook (20 I0) argues for secular climate shifts as a major factor in the decline and fall of several dynasties in the last millennium.

China historians may be more easily converted to the gospel of climate because Chinese texts often have detailed information about it, more so than the available texts from India and the Islamic world, for example. Gazetteers compiled more or less systematically since the Yuan dynasty (I 27 I-I 368) include weather observations, especially of strange anomalies. Indeed China historians and Chinese texts may be more predisposed than most to take climate seriously, because the concept of the Mandate of Heaven, important for two millennia in China, invests anomalous weather with political meaning. When floods, droughts or any meteorological mishaps seemed to come thick and fast, it was taken to mean the emperor and his lineage had lost the Mandate of Heaven, and thus the right to rule. Locust plagues, which apparently came more often on the heels of cold snaps, invited similar conclusions.

China's economy may also have proved more sensitive to climate shifts than economies elsewhere. Like other parts of Asia where irrigated rice was important, the quantity and timing of monsoon rains mattered deeply to Chinese harvests. Monsoons varied, partly in response to the giant Pacific climate oscillation known as El Niño or ENSO. Beyond this shared feature, the Chinese transportation system depended to an extraordinary degree on boat traffic on canals. The unique degree of marketization in China since the Song 
Dynasty (960-I279), matched nowhere in the world until perhaps the Netherlands in the seventeenth century, rested on networks of canals. When these froze, transport was hobbled. When they froze for more months than usual, cold year after cold year, the ability of the market (or the state) to move grain to areas of shortage was correspondingly diminished. China was, in effect doubly sensitive to climate shocks: both in the production of food and in its delivery.

The same cold and dry spells that were apparently devastating in China probably helped their chief enemies, the steppe peoples and Mongols in particular. (Brook does not make these arguments: they are my extrapolations from discussions of Mongol warfare).

For at least a century, some scholars have supposed that irruptions of pastoral nomads of the East Asian steppe were driven by episodes of drought. I expect that, at least some of the time, this was true in part. But perhaps the extraordinary cold of the thirteenth to fourteenth centries - now known in detail thanks to proxy evidence - made Mongol warfare easier? Frozen rivers and canals paralyzed transportation for China and inhibited it for most of the other peoples of Asia. But for Mongol war parties, frozen rivers and canals were highways. Given ice a few inches thick, they could move quickly and reliably through vegetated landscapes that in other conditions they would have had to try to burn to the ground in order to pass through.

Large patches of East Asia and Iran, and even larger ones of Russia and Eastern Europe, still carried forest cover in the thirteenth century. That forest provided barriers against equestrian forces - except when rivers or canals were frozen to sufficient depth for thousands of horses to ride along safely. The longer and colder the winter, the more mobile the Mongols, and the less mobile their enemies. Rivers usually led to cities, the prize targets. So to reduce this argument to its essence: the onset of the Little Ice Age cold raised the odds somewhat of Mongol military success, not on the steppe itself, but in China and especially in Eastern Europe. (Notice I do not say the Little Ice Age caused the Mongol success or permitted the Mongol success. It might have happened anyway - it was merely made more likely by the extraordinary cold.) This Mongol example is the only original one - at least I think it is original - in this paper, and 
should be distrusted as a result. It is only a hypothesis, yet to be tested against the evidence, such as the seasons of the year in which the Mongols did most of their campaigning and conquering. ${ }^{4}$

The most ambitious examples of text-based historians taking climate evidence and putting it at the center of an analysis are now Geoffrey Parker (20I3) and John Brooke (20I4). In a sprawling work, Parker catalogues the rebellions, revolutions, and wars of the seventeenth century, from southern Africa to Japan and from Southeast Asia to the Andes, and in almost every case finds a strong dose of adverse climate change - typically drought or cold associated with the Little Ice Age - prominent among the causes. Parker is a major figure in the community of historians of early modern Europe, as Bulliet is among Middle East historians and Brook among China historians. His work commands attention. Almost every historian working in the early modern period will need to confront Parker's analyses, and wrestle with the significance of the Little Ice Age.

Brooke (20I4), meanwhile, has attempted to put climate shifts and extreme climate events at the center of historical causation. His magnum opus takes the entire human career as its subject, and finds climate variables involved in almost every major historical episode until the end of the Little Ice Age. From about I 800 onwards, he argues, humankind has changed climate more than climate has affected us.

Dozens of ingenious and properly researched arguments about the significance of climate now exist in the historical literature. The situation is now far removed - and far better - from the facile formulae of Toynbee or the timid position of the early Le Roy Ladurie. Openness to the data coming from ice cores, pollen, tree rings, glaciers and so forth has made a gigantic difference in the strength and precision of arguments historians can now make.

Not only are the climate data better than ever, but the nuance and subtlety with which historians link climate to historical events has moved far beyond Toynbee. Besides the obvious and direct relevance of climate shifts to harvests, grain prices, famines, and social and political unrest - itself quite enough - historians have found climate shifts important in other ways, through other linkages. One is the changing populations of insect disease vectors, whether the 
fleas of bubonic plague or the tsetse flies of trypanosomiasis - or my beloved mosquitoes. Vector abundance is crucial in determining the prevalence of diseases such as malaria, dengue fever, or yellow fever. Another linkage is the impact of climate upon natural fire regimes, consequential in Australia, Indonesia, and western North America among other places. Yet another is the effect of climate shifts upon the movements of animals such as deer and fish, from which some peoples have at times drawn goodly portions of their livelihoods. Almost all these linkages concern climate's impact on basic human concerns, such as food supply and health.

Some of the arguments, no doubt, are overdone. I confess skepticism especially about some of the claims made for the deeper past for which we now have some climate proxy evidence but very little of other sorts, a situation that leads us into temptation. While historians of recent centuries are as a rule probably too skeptical about climate's significance, because they have too much other evidence, historians (and archeologists) of the deeper past are perhaps too credulous because they have too little.

Some historians, upon discovering the new proxy evidence on climate, write with the zeal of the convert. This is all the more reason for more historians to wade into the discussion, to bring their awareness of context and rival explanations to bear. But to do it responsibly and well, they must come to grips with the new evidence pouring forth from the natural sciences, and to practice, in effect, the new superhistory.

Soon historians will also need to take proper account of the human impact upon climate change rather than merely changing climate's impact upon humans. Le Roy Ladurie (2004-2009, 3) has begun to do this. Other scholars, not historians but geoscientists, have posited strong human impacts upon climate from the early millennia of agriculture, and claimed the depopulation of the Americas after I 492 deepened the Little Ice Age (Ruddiman 2005). The idea here is that resurgent vegetation in the Americas took carbon out of the atmosphere, weakening the greenhouse effect, and cooling the planet. Historians have yet to grapple seriously with Ruddiman's contentions. It remains to be seen whether historians will see their craft differently in an age of anthropogenic 
warming, as a prominent cultural historian, Dipesh Chakrabarty (2009), following in the path of Richard Foltz (2003) has recently urged that we should.

\section{Conclusion}

My conclusion takes the form of a parting question. Let us suppose historians do take climate seriously and continue to find more and more occasions, and more and more pathways, by which its oscillations affected human affairs. And suppose historians also find more occasions on which, and pathways by which, our affairs affected climate. At the beginning of this chapter I considered how the new kinds of evidence from the natural sciences might affect the choices historians make about geographical scale. But what about temporal scale? How might that evidence, and in particular, attention to climate change, affect the schemes of periodization that historians use and need?

We historians live with a cacophony of incompatible periodizations. In the Americas we typically have pre-Columbian, colonial, and national. Each of these is subdivided, and rather differently from place to place. Europeanists typically begin with ancient, medieval and modern, but subdivide those categories differently from place to place. Historians of India sometimes take these terms, but use them differently so that medieval India can last until I 857 . China historians use dynasties. African history features the pre-colonial, colonial, and independence periods, which has the curious consequence that almost all African history falls in the first of these periods, which ends about I885. George Brooks (1994) tried to create a periodization for West Africa based on the rhythms of wet and dry periods between the eleventh and seventeenth centuries, but his approach did not catch on.

The old habits are comfortable, and have with a bit of buffeting stood the tests of time. Feminist historians have raised questions - e.g. did women have a renaissance? (No, said Kelly (I977)). But they seem nonetheless to have accepted the basic frameworks. Other historians have asked whether India had an early modern period (Yes, said Richards (I997)). Global historians have struggled to find 
a single scheme into which to wedge all the twists and turns of world history, but without much luck to date (see the effort in Bentley I996). Will climate change ever seem powerful enough in human history to suggest its own scheme of periodization?

If not, will climate change rearrange our sense of continuities and discontinuities enough to make us question some, maybe most, of our periods? Will the end of antiquity come with the climate disasters of the 540s, felt throughout the world, rather than the sack of Rome in 476, which specialists now regard as merely a coup de grâce? Will the end of the Little Ice Age come to provide the distinction between early modern and modern? Will the onset of rapid warming create for historians a new period after 1950, which we now know variously as postwar, post-I945, postmodern, and after I960, postcolonial?

Unlike geologists, we historians are at liberty to adjust our periodization as we please. We can label any period anything we like, without consulting anyone. Geologists must propose any new vocabulary of periodization to a series of committees and ruling bodies, a process that is now in train for the term "Anthropocene", suggested to refer to the present period of the Earth's history in which humankind has played a preponderant role in shaping environmental processes. Geologists will formally decide, by vote, in 2016 as to whether or not the Anthropocene exists. In the meantime, historians, thanks to our institutional anarchy, can steal a march and begin to write the history of the Anthropocene, a history of a new age, for a new age, an age of - among other things - rapid climate change.

We will do so with new evidence, evidence from ice, from tree rings, from our own DNA, from that of camels and viruses, and no doubt from sources as yet unimagined. That evidence at times will corroborate the information coming from textual sources, and sometimes will challenge it. This presents a familiar quandary to historians, who have always had to reconcile divergent textual accounts. But we will need to learn new skills to parse the validity not only of one text versus another, but of texts versus isotopes and alleles. This is a revolution in historical method which, like most revolutions, will involve mistakes, confusion, and wasted effort. But, like most revolutions, it should be exciting and revealing nonetheless. 


\section{Notes}

I In addition to early practitioners such as Rashid al-Din, Ibn Khaldun, or Sir Walter Ralegh, see the twentieth-century tradition of world and global history, excerpted and analyzed in works such as Manning 2003; Dunn 1999; Costello I995; Bentley 2012.

2 Not Bernard Bailyn (I982), who wrote about "manifest history" and "latent history".

3 Le Roy Ladurie was substantially influenced by the Swedish scholar Gustaf Utterström, especially Utterström I955.

4 My remarks here were composed before the appearance of a fascinating and provocative paper by an interdisciplinary team that seeks to explain early Mongol success by reference to a few years of above-average rainfall in the Mongols' homeland. This fifteen-year period, I 2 I I-I 225 , is the only one over the past I, I I 2 years that shows above average rainfall in every year, so it amounts to a unique moment in the history of the Mongolian steppe. According to this argument more rainfall meant more grass, more sheep and ponies, and more Mongols, giving them an advantage in numbers (both of people and ponies) over their neighbors who did not enjoy the same good meteorological fortune. This argument, based on tree ring evidence from Mongolia, refers to the early Mongol expansion, not their subsequent conquests in China, Iran, and Russia for which (I claim) cold climate was helpful. See Pederson et al. 2014.

\section{References}

Bailyn, Bernard. 1982. "The Challenge of Modern Historiography", American Historical Review 87, I-24.

Beach, T., Luzzadder-Beach, S., Cook, D., Dunning, N., Kennett, D., Krause, S., Terry, R., Trein, D. \& Valdez, F. 20 I 5. "Ancient Maya Impacts on the Earth's Surface: An Early Anthropocene Analog?”, Quaternary Science Reviews I 24, I-30.

Behringer, Wolfgang. I999. "Climatic change and Witch-Hunting: The Impact of the Little Ice Age on Mentalities”, Climatic Change 43, 335-35 I.

Bentley, Jerry. I996. "Cross-cultural Interaction and Periodization in World History", American Historical Review I0 I, 749-770.

(ed.). 20I 2. Oxford History Handbook to World History. Oxford: Oxford University Press.

Brook, Timothy. 2010. The Troubled Empire. Cambridge, MA: Harvard University Press. Brooke, John. 20 I 4. Climate Change and the Course of Global History: A Rough Journey. New York: Cambridge University Press.

Brooks, George. 1994. Landlords and Strangers: Ecology, Society, and Trade in Western Africa, 1000-I630. Boulder: Westview Press.

Bulliet, Richard. 2009. Cotton, Climate, and Camels in Early Islamic Iran: A Moment in World History. New York: Columbia University Press.

Caldeira, Ken. 20 I 2. "The Great Climate Experiment", Scientific American 307(3), 79-83. Chakrabarty, Dipesh. 2009. "The Climate of History: Four Theses”, Critical Inquiry 35. 
Christian, David. 2005. Maps of Time: An Introduction to Big History. Berkeley: University of California Press.

Costello, Paul. I995. World Historians and their Goals. De Kalb, IL: Northern Illinois University Press.

Dunn, Ross. (ed.) 1999. The New World History. New York: Bedford/St. Martin's.

Ellenblum, Ronnie. 20I2. The Collapse of the Eastern Mediterranean: Climate Change and the Decline of the East, 950-1072. Cambridge: Cambridge University Press.

Foltz, Richard. 2003. "Does Nature Have Historical Agency? World History, Environmental History, and How Historians Can Help Save the Planet", The History Teacher 37, 9-28.

Glacken, Clarence. 1967. Traces on the Rhodian Shore. Berkeley: University of California Press.

Ibn Khaldun [Abū Zayd 'Abd ar-Rahmān ibn Muhammad ibn Khaldūn al-Hadramī]. 1967. The Muqaddimah: An Introduction to History. [transl. Franz Rosenthal]. Princeton: Princeton University Press.

Kelly, Joan. 1977. “Did Women Have a Renaissance?”, in Renate Bridenthal \& Claudia Koonz (eds.), Becoming Visible: Women in European History. Boston: Houghton: I37-163.

Le Roy Ladurie, Emmanuel. 1967. L'histoire du climat depuis l'an mil. Paris: Flammarion.

- 2004-2009. Histoire humaine et comparée du climat, 3 vols. Paris: Fayard.

Manning, Patrick. 2003. Navigating World History. London: Palgrave.

McNeill, J.R. 20 Io. Mosquito Empires: Ecology and War in the Greater Caribbean, I620-I9I4. New York: Cambridge University Press.

Miller, Joseph. 1988. The Way of Death. Madison: University of Wisconsin Press.

Montesquieu, Charles de Secondat, Baron de. I 856 [1748]. L'Esprit des Lois. Paris: Firmin Didot frères.

Myrdal, Janken. 20 I 2. "Source Pluralism as a Method of Historical Research", in Susanna Fellmann \& Marjata Rahikaiinen (eds.), Historical Knowledge: In Quest of Theory, Method, and Evidence. Newcastle: Cambridge Scholars Press.

Parker, Geoffrey. 2013. Global Crisis: War, Climate Change, and Catastrophe in the Seventeenth Century. New Haven: Yale University Press.

Pederson, Neil, Hessl, Amy, Baatarbileg, Nachin, Anchukaitis, Kevin \& di Cosmo, Nicola. 20I4. "Pluvials, Droughts, the Mongol Empire and Modern Mongolia", Proceedings of the National Academy of Sciences I I I, 4375-4379.

Richards, John F. I997. "Early Modern India and World History", Journal of World History 8, 197-209.

Ruddiman, William. 2005. Plows, Plagues and Petroleum. Princeton: Princeton University Press.

Spier, Fred. 20 I o. Big History and the Future of Humanity. Chichester: Wiley-Blackwell.

Stahle, D.W. et al. 20 I . "Major Mesoamerican Droughts of the Past Millennium", Geophysical Research Letters, 38, L05703.

Toynbee, Arnold J. 1934-6I. A Study of History. I 2 vols. Oxford: Oxford University Press. Utterström, Gustaf. 1955. "Climatic Fluctuations and Population Problems in Early Modern History", Scandinavian Economic History Review 3, 3-47.

White, Sam. 20 I I. The Climate of Rebellion in the Early Modern Ottoman Empire. New York: Cambridge University Press. 